\title{
PALEOSEISMOLOGICAL INVESTIGATONS ALONG THE KERA FAULT ZONE, WESTERN CRETE: IMPLICATIONS FOR SEISMIC HAZARD ASSESSMENT
} V. MOUSLOPOULOU ${ }^{1}$, C. ANDREOU, ${ }^{1}$ K. ATAKAN ${ }^{2}$, I. FOUNTOULIS ${ }^{1}$

\begin{abstract}
The island of Crete is the principal landmass in the Aegean arc system. Collision of the Euroasian plate in the north and the African plate in the south gives rise to the subduction related deformation along the Hellenic arc. As a result of the complex deformation, the area is characterized by high seismic activity. Paleoseismic investigations performed along the Kera fault scarp, which is part of a N-S oriented fault system along the Spatha peninsula (NW-Crete), show clear evidence of repeated normal faulting events. Five distinct episodes of faulting are observed. The first two are probably of Middle-Miocene or younger age representing older tectonic episodes, whereas the last three indicate co-seismic displacements most likely during the Pleistocene and Holocene. This is in good agreement with the previous estimates of Holocene average slip rate and the recurrence time estimate of large earthquakes in the order of ca. $1 \mathrm{~mm} / \mathrm{yr}$ and $3000 \mathrm{yrs}$, respectively. The Kera fault represents a NE-SW oriented bend in a N-S fault system and therefore has a minor left-lateral strike-slip component. During the 1980's at least three earthquakes could be associated with the Kera fault. More recently, in 1999, there were three small (with magnitudes between 3.0-4.5) offshore events that are probably associated with the same fault system in the offshore extension (to the north) of the N-S oriented faults along the Spatha peninsula. The existence of these earthquakes as well as the recent paleoseismic results clearly demonstrates the need of revising the seismic hazard assessment of the area. The length of the N-S oriented fault system, where the Kera fault represents the middle segment, reaches to a total of $30 \mathrm{~km}$., and is capable of generating an earthquake of magnitude in the range 6.0-6.7. Such a (shallow) earthquake occurring at a short distance to the densely populated north-western coast of Crete is likely to have significant consequences.
\end{abstract}

KEY WORDS: Palaeoseismology, active fault, colluvial wedge, earthquake event.

\section{INTRODUCTION}

Crete is the main island in the Aegean arc system (Hellenic arc), which lies at the southern margin of the Aegean continental block. The Hellenic arc is a convergent zone associated with northward subduction of the African plate beneath the Aegean (Fig. 1). The western part of Crete is located in one of the tectonically and seismically most active areas of the Africa-Eurasia collision zone.

The study area is a complex multi-fractured neotectonic macrostructure, which is characterized by the presence of large grabens and horsts bounded by wide fault zones, trending approximately N-S. Inside these firstorder neotectonic macrostructures a considerable number of small order structures are present (Fig.2).

Western Crete is dominated by extensional tectonics as expressed by the N-S oriented normal faults on the northwestern part of the island (Fig.2). The deep-seated compressional tectonics is not in contradiction with the extensional features observed on shallow structures on the upper plate. The extensional structures (local depressions/basins, normal faults) which are present in the area, may be of secondary origin of an almost transtensional or transpressional field (Pavlakis, 1993). Many geophysical, geological and paleomagnetic investigations were conducted in the south Aegean, dealing with the crustal structure and the seismic hazard of the Cretan segment (Papadopoulos and Kijko, 1991, Knapmeyer and Hans-Peter Harjes 2000, Manakou and Tsapanos, 2000). Mariolakos \& Papanikolaou (1987), claim that the deformation pattern of the area is not only a result of axial extension but also a result of simple shear and torsion The peninsula of Spatha behaves as a tectonic dipole, which is rotating round an almost horizontal N-S axis towards east. The peninsula of Gramvousa behaves also as a tectonic dipole consisting of two blocks separated by the old, almost E-W oriented, set of faults. The north block is moving westward whereas the south segment is moving eastward. The uplifted and

1. Department of Geology, University of Athens, Panepistimioupolis Zografou, 15784 Athens,Greece. E-mail: fountoulis@geol.uoa.gr

2. Institute of Solid Earth Physics, University of Bergen Allegt. 41, N-5007 Bergen, Norway. E-mail: kuvvet.atakan@ifjf.uib.no 


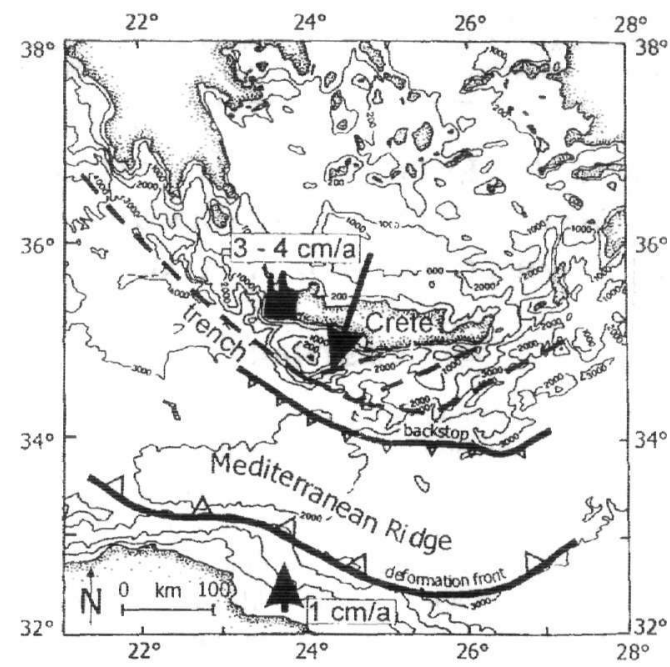

Fig.1: Present geodynamic setting of the Hellenic arc and the relevant displacements (cm/a) of Crete and Africa in relation to the stable Europe. The study area on Crete is shaded. (after Papanikolaou, 1999).

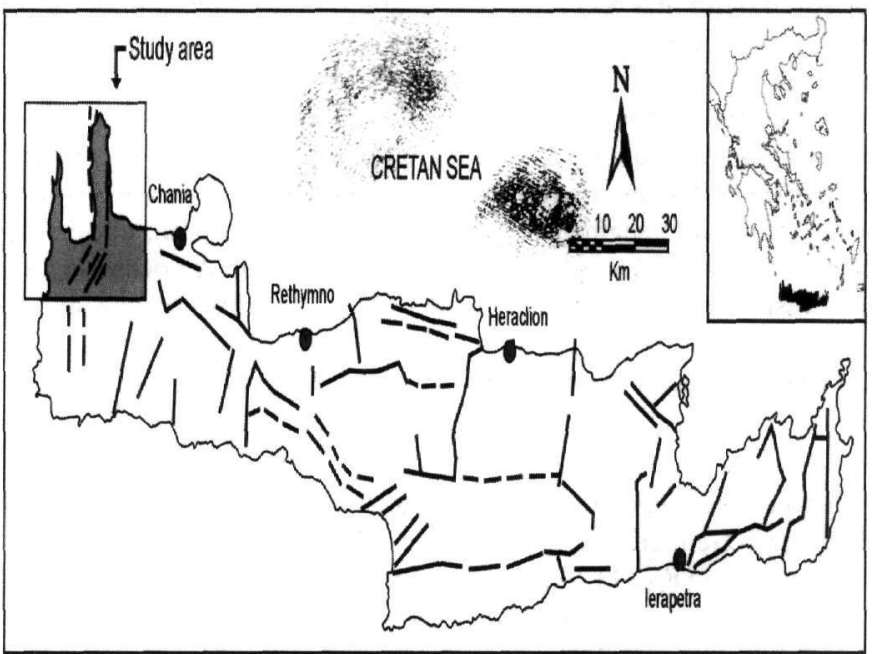

Fig.2: Simplified map showing the major fault zones on the island of Crete.

submerged shorelines, observed at the edges of this dipole confirm this picture (Pirazzoli et al, 1982). As a result of a complex deformation, the area is characterized by high seismic activity. Both historic and recent earthquake data indicate that the N-S oriented extensional faults are active (Fig. 3).

\section{PALAEOSEISMOLOGY OF THE KERA FAULT}

The paleoseismological investigations were performed on two trenches which were excavated on the Kera fault zone (the work on the third trench didn't progress due to limited preservation of its units). Kera fault represents a NE-SW oriented bend in a N-S normal fault system along the Spatha peninsula and therefore has a minor left lateral strike slip component, which is compatible with pure E-W extension (strike: $036^{\circ} \mathrm{NE}$, dip: $70^{\circ} \mathrm{NW}$ and rake: $20^{\circ} \mathrm{SW}$ ) (Fig. 3). 


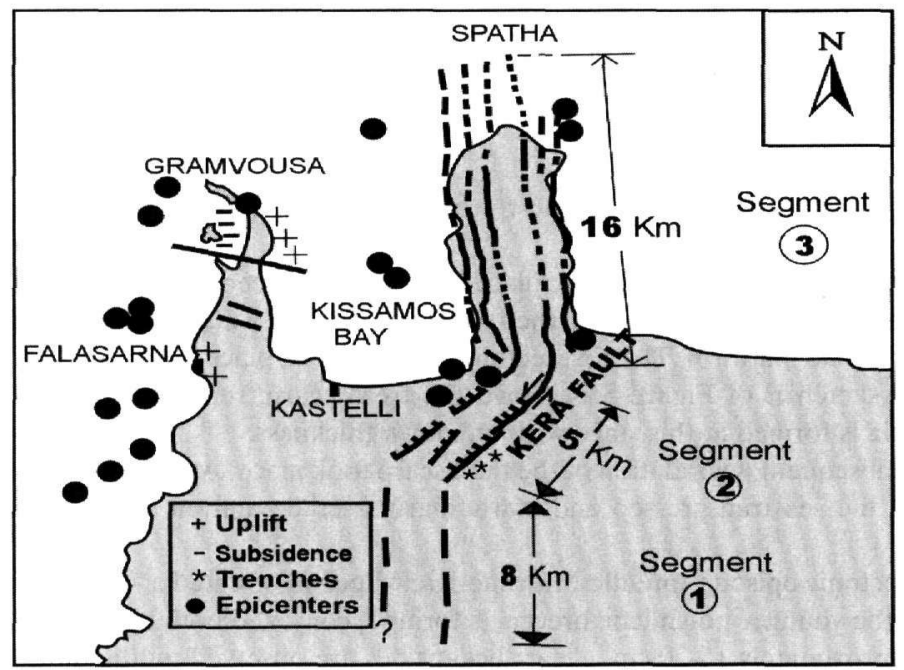

Fig. 3: Map showing the three segments of the active fault zone. Kera fault represents the shorter segment in the middle of the map, with a NE-SW orientation. The ascendent and descendent movements on Gramvousa peninsula are shown. Recent earthquake activity is also noted (NOA, 1964-1999, M>4.5) (after Mouslopoulou, 1999).

The fault scarp was studied and seven different units were identified on both trenches. The reconstruction of the geological history was based mainly on the evidences derived from the logging of the two trenches. Fig.4 shows the interpreted log in one of these trenches.

On the Kera fault scarp, due to temporal and financial limitations, no dating techniques have been performed. The analysis, which was based on the deposition of the colluvial wedge sediments, provided us with some relative ages. It showed that the fault has been reactivated many times in the past, as early as upper Cretaceous. At least five tectonic events (normal faulting with some minor oblique component) were recognized on the two trenches along the Kera fault. The two first tectonic episodes represent a very old period of deformation since they occurred in a time span of upper Cretaceous - upper Miocene. The two breccias observed on the fault surface today, are the cumulative result of a series of tectonic episodes, which took place during this older period. It is obvious that these two breccias represent a series of deformational episodes rather than individuals earthquakes.
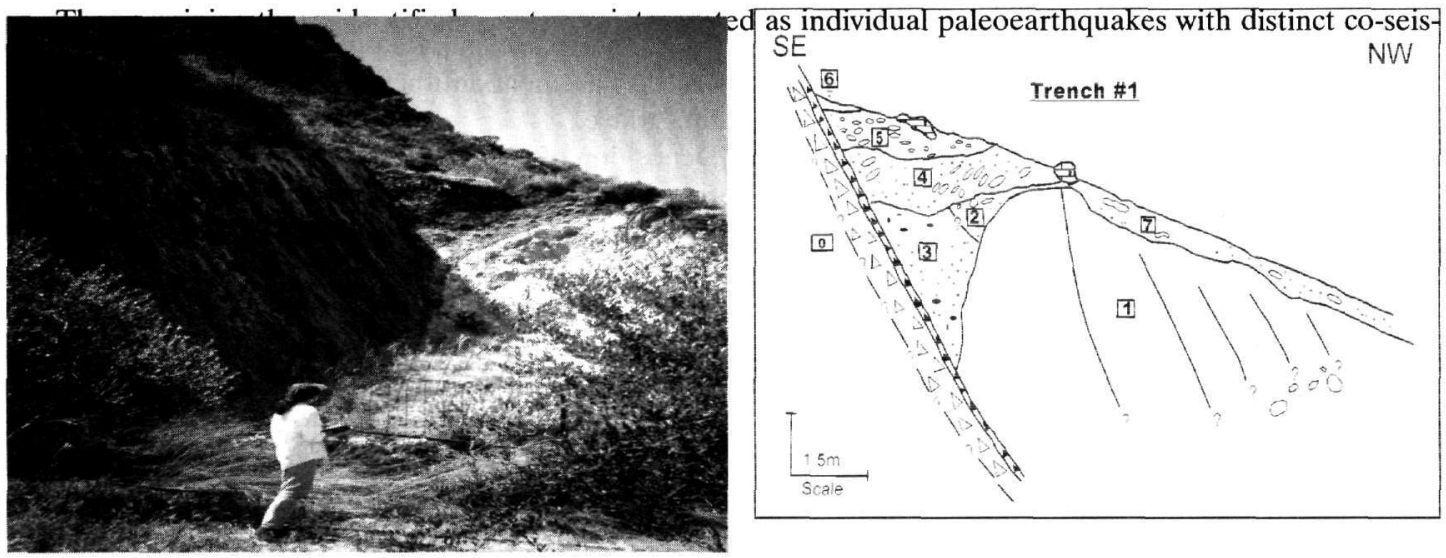

Fig.4: On the top of the figure the trench log section with the seven identified sedimentary units is shown (see text for description of the units). On the left picture showing, the field location of the Trench \#1. 
mic displacements as indicated from the deformed colluvial wedges. The fact that the colluvial wedges, derived from the fault scarp, are still unconsolidated indicates that these last three events occurred most likely in Quaternary. The last event may have occurred even in Holocene period, since there is still a fresh scarp visible on the fault surface.

Following there is a short description of the retrodeformation based on the interpretations made on the trenches (see Figs. 4, 5).

- (A) Marine (carbonate) sedimentation took place in Upper Cretaceous. Prefaulting stratigraphy.

- (B) At this stage a general uplift resulted in the regression of the sea and the local revelation and subsequent erosion of the carbonate platform. The first tectonic episode took place during the upper Cretaceous-middle Miocene. On the sketch B of Figure 5 is shown the fresh scarp, representing the first tectonic episode. Oligomictic breccia is formed at this stage with unknown thickness.

- (C) Erosion and subsequent degradation of the fault scarp took place. At the same time, at the neighborhood of the fault zone, the sea transgressed and marly marine sedimentation is commenced off-shore (middle Miocene).

- (D) The second tectonic episode (middle Miocene-late Miocene) created a free face in the limestones (unit 0 ). At that stage, the younger polymictic breccia is formed, consisted both of carbonate and marly material. Its thickness is approximately $15-20 \mathrm{~cm}$. Clear slickensides are observed on the fault slip surface (70/036).

- (E) After the formation of the previous fault scarp, the first colluvial wedge is deposited. It is mainly composed of carbonate and marly material. This wedge corresponds to the defined units $2 \& 3$ that have been recognized during the logging of the trenches. The time that has elapsed between the formation of the first, oligomictic breccia (first tectonic episode), and the following third earthquake, may be as large as $55 \mathrm{Ma}$.

- (F) Third faulting event (interpreted as a paleoearthquake) took place during the post-Miocene period and created a new free face in the limestones (unit 0), and a new basal tension fissure into which the earlier colluvial wedge is drooped. A small-displacement antithetic faulting, formed in unconsolidated sediments, should have occurred during this stage.

- (G) The previous fault scarp was weathered and erosional processes started to degrade. Second colluvial wedge was formed. This wedge is mainly composed of limestone and marly material and corresponds to the defined unit 4 (conglomerate) shown in the trenching.

- (H) Fourth faulting event (interpreted as a paleoearthquake), which should have taken place at the Pleistocene or even Holocene geological period, created a new free face in the limestone unit and a new basal tension fissure into which the earlier colluvial wedge is deposited. At this stage, there are also indications (changes of the clasts size) that antithetic faulting took place.

- (I) Erosion and subsequent degradation of the fault scarp occurred after the forth event. Deposition of the third colluvial wedge took place, which buried the earlier two wedges. Later on, this colluvial wedge propagated out onto the downthrown block. It is composed of material derived from the limestones (unit 0 ), the marls (unit 1) and the conglomerates (unit 4), and corresponds to unit 5.

- (J) Fifth faulting event (interpreted as a paleoearthquake) took place and, for once more, a new fresh scarp was formed on the limestones. At the same time, small displacement antithetic faulting occurred, creating disturbances to the clasts of the units, all along the slip surface.

- (K) Present day situation of the trench is indicated. Deposition of the forth colluvial wedge is overlying the previous ones. This last wedge corresponds to the defined unit 6 (fine conglomerate clasts) and appears as a small outcrop. After the fourth faulting event the scarp became relatively stable. During this stability a soil would form on the colluvium. Indeed, a thin dark-colour soil cover is formed at the top of all the units and corresponds to the defined unit 7.

Concerning the fresh scarp that exists on the surface, two alternative interpretations may be given: either it is the result of the fifth faulting event, which has not been completely smoothed by the erosion, or this is the result of the most recent earthquake (a sixth one). Existing data does not allow reaching to a conclusion.

In order to estimate the paleoearthquake size, we have used the fault's length. Assuming the surface rupture, only along the length of the Kera fault segment (Fig.3) and using the Wells and Coppersmith (1994) relation $\mathrm{M}=5.08+1.16^{*} \log (\mathrm{SRL})$, the minimum magnitude estimated is $\mathrm{M} 5.9( \pm 0.2)$. Since the Kera fault consists an intermediate segment of a broader fault zone it may tectonically interact with the segments that surround it (in spite the fact that the segments 1 and 3 have no indications of recent reactivation). Thus, if we 


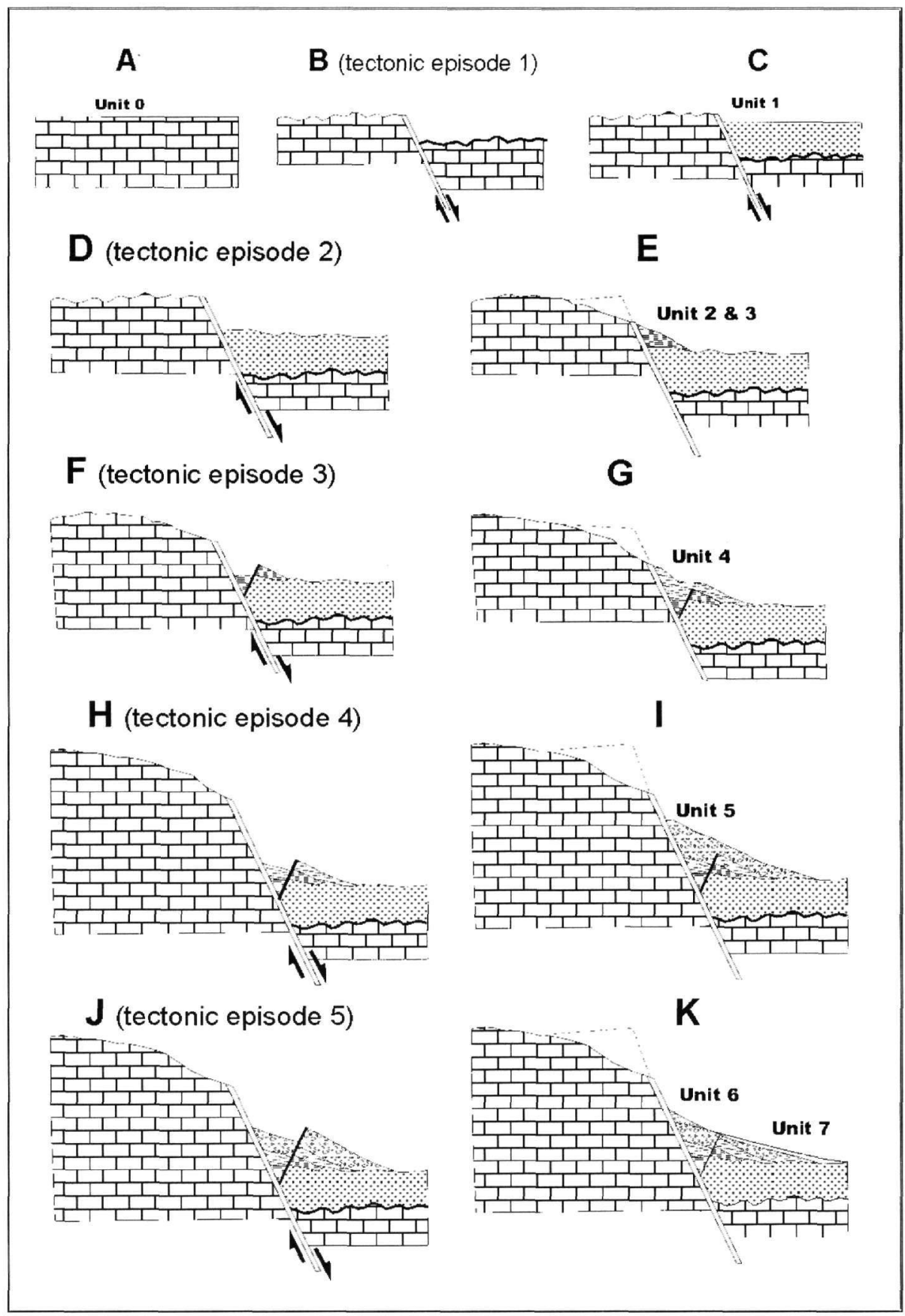

Fig 5: Retrodeformation of the Kera fault zone (schematic, not in scale): A. Upper Cretaceous carbonate marine sedimentation. B. First tectonic episode. Formation of the Oligomictic breccia. C. Erosion of the fault scarp.

Transgression and marly sedimentation (middle Miocene). D. Second tectonic episode. Formation of the polymictic breccia. E. Deposition of the first colluvial wedge. F. Third faulting event (post-Miocene time) (seismic event 3). G. Erosion and degradation of the fault scarp. Deposition of the second colluvial wedge. $H$. Fourth faulting event (Quaternary) (seismic event 4). I. Erosion of the fault scarp causes the deposition of the third colluvial wedge. J. Fifth faulting event (Quaternary) (seismic event 5). K. Deposition of the fourth colluvial wedge and formation of a thin soil horizon. 
assume the rupture along the $1^{\text {st }}$ and $2^{\text {nd }}$ segments together $(13 \mathrm{~km})$, we come up with a minimum magnitude in the order of M $6.3( \pm 0.1)$. Assuming the length of the $2^{\text {nd }}$ and $3^{\text {rd }}$ segments together $(21 \mathrm{~km})$, we come up with a minimum magnitude in the order of $\mathrm{M} 6.6( \pm 0.08)$. Finally assuming that the entire, $30 \mathrm{~km}$ long, $\mathrm{N}-\mathrm{S}$ orientated fault system (segments $1+2+3$ ) was ruptured simultaneously through a single earthquake, then, a magnitude of up to $6.7( \pm 0.05)$ may have occurred in the area.

\section{DISCUSSION - CONCLUSIONS}

The tectonic setting on which Kera fault system lays, is probably far more complicated than a simple axial E$\mathrm{W}$ extensional regime. It is also likely that this extension is a local superficial phenomenon, deriving from an almost, deep in the crust, transpressional field, and hence the N-S oriented extensional structures observed on western Crete could be regarded as of secondary origin.

Taking into account the observed fault pattern we can correlate it with the recent seismicity of the area. There are, indeed, earthquakes occurred in the vicinity of the Kera fault during the last decades. More specifically, during the 80 's three earthquakes could be associated with the Kera fault (1980, 1987, 1988-with magnitudes between 4.5-5.2) (Fig. 3) whereas, early 1999, there were three small $(3.0<\mathrm{M}<4.5)$ offshore events that are probably associated with the same fault system in the offshore extension (to the north) of the N-S oriented faults along the Spatha peninsula. Moreover, historical documents reveal at least five earthquake events felt in the broader area of Crete from the antiquity until 1910. The magnitudes of these earthquakes were $>6.0$ (Andreou, 2000). From these inferences it is obvious that the study area is located in a tectonic setting, which is capable of generating earthquakes of significant magnitudes.

Taking into account all the above inferences, the following conclusions can be made:

1. Kera fault zone show clear evidence of repeated normal faulting events. At least 5 reactivations have been observed on the Kera fault scarp since the time of its formation.

2. It is likely that some of those reactivations occurred in Holocene. There are five strong events that have occurred during the last two millenniums. The last event on the Kera fault may be associated with some of the historic earthquakes.

3. Although there are not direct evidences of recent reactivation along the $1^{\text {st }}$ and $3^{\text {rd }}$ segments, it, definitely, cannot be excluded the possibility of combined reactivation of all, three, of them. So, the $30 \mathrm{~km}$ long N-S oriented fault system along Spatha peninsula is capable of generating an earthquake of magnitude in the range 6.0-6.7.

Thus, it is evident that in the area of western Crete, seismic activity continues until the present day. Such a shallow earthquake occurring at a short distance to the densely populated northwest coast of Crete is likely to have significant consequences.

Summarizing this study, the following recommendations can be made:

The recent earthquake activity on western Crete and the evidences derived from the study area, manifest that the N-S oriented fault system is active. Assuming that the last large earthquake event on Kera fault zone occurred in Holocene and taking into account the recurrence time of 3000yr (Armijo et al., 1992), it becomes obvious that a more careful assessment of the seismic hazard potential of the region is required.

The conclusions drawn in this study are based on observations derived from a limited study area. In order to improve the understanding of the active tectonics in the area, a more detailed investigation, both on the Kera fault as well as other potentially active faults needs to be carried out in the future. Moreover, the fact that the island of Crete is densely populated, strengthens the argument stated above.

Acknowledgments: This study was partly supported by the Norwegian Research Council and the Mathematics and Natural Sciences faculty of the University of Bergen.

\section{REFERENCES}


ANDREOU C., 2000. Seismic Hazard Analysis Of Western Crete And Kythira Strait, Institute of Solid Earth Physics, University of Bergen, pp.1-180.

ARMIJO, R., LYONCAEN, H., PAPANASTASSIOU, D., 1992. East-West extension and Holocene normal-fault scarps in the Hellenic arc. Geology, vol. 20, Nr. 6, 491-494.

DRAKOPOULOS, J., FYTROLAKIS, N., DELIBASIS, N. AND MAKROPOULOS, K., 1983. The seismotectonic map of Crete. Publ. by Technical Chamber of Greece, Div. East and West Crete, 26 pp. (in Greek).

HALL, R., AUDLEY-CHARLES, M.G AND CARTER, D.J., 1984. The significance of Crete for the evolution of eastern Mediterranean. In: J.E. Dixon and A.H.F. Robertson (Editors), The Geological Evolution of eastern Mediterranean, Spec. Iss., Geol. Soc. London, 499-516.

KNAPMEYER, M AND HARJES, H-P., 2000. Imaging crustal discontinuities and the downgoing slab beneath western Crete. Geophys. J.Int., 143, 1-21.

LE PICHON, X. AND ANGELIER, J., 1979. The Hellenic arc and trench system: a key to the neotektonic evolution of the eastern Mediterranean area. Tectonophysics, 60, 1-42.

LYON-CAEN, H., ARMIJO, R., DRAKOPOULOS, J., BASKOUTASS, J., DELIBASSIS, N., GAULON, R., KOUSKOUNA, V., LATOUSSAKIS, J., MAKROPOULOS, K., PAPADIMITRIOU, P., PAPANASTASSIOU, D., AND PEDOTTI, G., 1988. The 1986 Kalamata (South Peloponnesus) earthquake: Detailed study of a normal fault, evidences for east-west extension in the Hellenic arc: Journal of Geophysical Research, v.93, p.14967-15000.

McCALPIN, J., 1996. Paleoseismology, 1-585 p., Edit. by Academic press.

MAKRIS, J. 1977. Geophysical investigations of the Hellenides. Hamp. Geoph. Einz, R.A. 34, 1-124.

MANAKOU, M.V. AND TSAPANOS, T.M., 2000. Seismicity and seismic hazard parameters evaluation in the island of Crete and the surrounding area inferred from mixed data files. Tectonophysics, 321, 157-178.

MARIOLAKOS, I. AND PAPANIKOLAOU, D., 1987. Deformation pattern and relation between deformation and seismicity in the Hellenic arc. Bull. Geol. Soc. Greece. vol. XIX, p.p. 59-76, Athens.

MOUSLOPOULOU,V., 1999. Active tectonics in Western Crete and Paleoseismological investigations along the Kera fault zone. Cand. Scient. Thesis, Bergen, Norway.

PAPADOPOULOS, G.A. AND KIJKO, A., 1991. Maximum likehood estimation of earthquake hazard parameters in the Aegean area from mixed data. Tectonophysics, 185, 277-294.

PAPANIKOLAOU, D., 1999. The subduction zone along the Hellenic arc: A unique location of backward moving margins in convergent lithospheric plates. In: Scientific American (Greek version), vol.A., pp. 25-29.

PAVLAKIS, P., 1993. The strike slip tectonic regime at Southern Aegean sea as implied by combined marine geophysical survey. Bull. Geol. Soc. Greece, vol. XXVIII/3, 253-273.

PIRAZZOLI, P.A., Tho mmeret, J., Thommeret, Y., Laborel, J. and Montagionni, L.F., 1982. Crustal block movements from Holocene shorelines: Crete and Antikythira (Greece). Tectonophysics, 86, 27-43.

WELLS, D.L. AND COPPERSMITH, K.J., 1994. Empirical relationships among magnitude, rupture length, rupture area, and surface displacement. Bull. Seismo. Soc. Am. 84, 974-1784. 